\title{
Timbulan dan Pengurangan Sampah di Kecamatan Klojen Kota Malang
}

\author{
Rizqi Meuthia Widyaningsih dan Welly Herumurti \\ Departemen Teknik Lingkungan, Fakultas Teknik Sipil dan Perencanaan (FTSP), Institut Teknologi \\ Sepuluh Nopember (ITS) \\ Jl. Arief Rahman Hakim, Surabaya 60111 Indonesia \\ e-mail: herumurti@enviro.its.ac.id
}

\begin{abstract}
Abstrak - Kecamatan Klojen merupakan salah satu kecamatan di Kota Malang yang memiliki kepadatan penduduk paling tinggi dengan kontribusi sampah terbesar yaitu kurang lebih sekitar $38,00 \mathrm{~m}^{3} / \mathrm{hari}$ dengan jumlah penduduk terendah. Besarnya timbulan sampah mengakibatkan penumpukan sampah di TPS. Manajemen Bank Sampah Malang (BSM) merupakan salah satu program yang dibuat untuk membantu pemerintah daerah dalam mereduksi sampah khususnya yaitu sampah anorganik dan mendorong perilaku memilah sampah. Data primer yang dibutuhkan antara lain pengukuran timbulan dilakukan selama 8 hari. Pemilihan lokasi sampling berdasarkan hasil pemetaan TPS. Data reduksi sampah didapatkan dari wawancara dan pengukuran komposisi sampah tereduksi oleh bank sampah, petugas pengumpul sampah, dan sektor informal. Data reduksi juga didapatkan dari pengukuran langsung terhadap hasil pilahan dengan cara menimbang. Laju timbulan sampah rumah tangga di Kecamatan Klojen adalah sebesar $0,28 \mathrm{~kg} /$ orang/hari. Komposisi sampah sejenis sampah rumah tangga terdiri dari dikomposkan sebesar sebesar $\mathbf{6 7 , 2 9 \%}$, sedangkan komposisi lainnya terdiri dari sampah plastik 8,29\%, diapers $8,00 \%$, kertas $7,22 \%$, kain 1,90\%, logam 1,78\%, kaca 1,06\%, kayu 0,09\%, karet $0,15 \%$, residu $3,66 \%$, dan $B 30,57 \%$. Reduksi sampah di sumber dilakukan oleh masyarakat melalui Bank Sampah dan sektor informal. Jumlah bank sampah yang ada di Kecamatan Klojen sebanyak 93 bank sampah. Persentase pelayanan Bank Sampah di Kecamatan Klojen sebesar 14,6\%. Pengurangan sampah melalui Bank Sampah sebesar 1,1\%. Sedangkan pengurangan sampah melalui sektor informal sebesar $2,6 \%$.
\end{abstract}

Kata Kunci-Bank sampah, komposisi, reduksi sampah, sampah rumah tangga, timbulan.

\section{PENDAHULUAN}

$\mathrm{K}$ ENAIKAN taraf hidup masyarakat mengakibatkan perubahan pola konsumsi masyarakat sehingga secara tidak langsung juga mempengaruhi timbulan sampah yang dihasilkan setiap hari [1]. Kondisi tersebut juga terjadi di Kota Malang, peningkatan jumlah penduduk dan beragamnya aktivitas yang dilakukan penduduk diperkirakan mempengaruhi peningkatan volume timbulan sampah secara signifikan [2]. Berdasarkan Memorandum Program Sektor Sanitasi Kota Malang Tahun 2012-2015, pola pemilahan sampah organik dan non organik di Kota Malang belum dilakukan secara maksimal. Permasalahan lain yang ada saat ini adalah adanya Tempat Penampungan Sementara (TPS) yang belum mampu menjangkau seluruh masyarakat perkotaan dan semakin berkurangnya daya tampung Tempat Pemrosesan
Akhir (TPA), sementara sampah yang ditampung semakin lama semakin banyak [3].

Jumlah timbulan sampah di Kota Malang adalah sekitar \pm 660 ton/hari dimana sebagian besar sampah berasal dari rumah tangga, dan sisanya berasal dari pasar dan limbah industri [4]. Sampah Kota Malang menunjukkan sekitar bahwa 69\% sampah berasal dari sampah domestik yaitu dari perumahan atau rumah tangga sedangkan sisanya $31 \%$ berasal dari sampah non domestik yaitu dari sampah pasar, fasilitas pertokoan, fasilitas industri, sampah jalan, sampah pertamanan dan sampah dari fasilitas kesehatan [5]. Sedangkan laju timbulan sampah Kota Malang sebesar 3,2 L/orang/hari [6]. Berdasarkan hasil analisis, timbulan sampah di Kota Malang pada tahun 2016 adalah sebesar $164,80 \mathrm{~m}^{3} /$ hari. Kecamatan Klojen merupakan wilayah dengan kontribusi sampah terbesar yaitu kurang lebih sekitar $38,00 \mathrm{~m}^{3} /$ hari dengan jumlah penduduk terendah di Kota Malang [2]. Kemungkinan tingginya timbulan sampah di Kecamatan Klojen karena terdapat banyak fasilitas umum di Kecamatan Klojen [3].

Pemerintah telah mencanangkan program di Kota Malang yang pada dasarnya untuk meningkatkan partisipasi masyarakat dalam upaya pengelolaan sampah berbasis pemberdayaan masyarakat [7]. Manajemen Bank Sampah Malang (BSM) merupakan suatu kegiatan inovatif masyarakat yang mengajarkan masyarakat untuk memilah sampah dan mengelola sampah secara bijaksana. Prinsip utama dari bank sampah yaitu melibatkan dan memberdayakan masyarakat [8]. Berdasarkan Data Nasabah Bank Sampah Malang tahun 2013, jumlah Bank Sampah Kota Malang sebanyak 282 kelompok dimana 60 kelompok bank sampah terdapat di Kecamatan Klojen [9]. Bank Sampah akan memberikan kontribusi dalam pengurangan volume sampah. Pengaruh bank sampah, pengepul dan sektor informal (petugas pengumpul sampah, pemulung) dalam mereduksi sampah rumah tangga belum terukur dan tidak diketahui secara pasti. Hal ini penting untuk diketahui dalam menentukan kesetimbangan masa sampah, pola daur ulang sampah dan pengelolaan sampah yang dilakukan.

Reduksi sampah rumah tangga yang melibatkan partisipasi masyarakat perlu dilakukan untuk meningkatkan pelayanan pengumpulan sampah atau optimasi pengumpulan sampah. Reduksi sampah rumah tangga dapat mengurangi beban sampah yang masuk ke TPS. Sehingga dalam penelitian ini dilakukan penentuan timbulan, karakteristik, dan potensi reduksi sampah melalui Bank Sampah dan sektor informal. 
Adanya pengurangan sampah diharapkan dapat membantu pemerintah dalam pengelolaan sampah di Kecamatan Klojen.

\section{METODE PENELITIAN}

\section{A. Penentuan Wilayah Penelitian}

Penentuan wilayah penelitian ini didasarkan pada pemetaan area pelayanan sampah di masing-masing TPS ataupun random sampling. Random sampling dilakukan dengan pemilihan secara acak. Pengambilan data sampling meliputi timbulan, komposisi dan densitas sampah rumah tangga. Penentuan wilayah penelitian juga dilakukan dengan pengamatan langsung dan informasi yang diperoleh dari instansi pemerintah, seperti kantor kecamatan dan Badan Pusat Statistik, mengenai kondisi eksisting daerah dan kependudukan pada lokasi studi.

Penentuan jumlah sampel sampah yang akan diambil menggunakan metode SNI 19-3964-1994 adalah sebagai berikut:

$\mathrm{S}=\mathrm{Cd} \sqrt{\mathrm{Ps}}$

Dimana:

$\mathrm{S} \quad=$ jumlah contoh sampel (jiwa)

$\mathrm{Cd}=$ koefisien kota metropolitan dan besar $=1$

Ps $=$ Populasi (jiwa)

$\mathrm{K}=\frac{\mathrm{s}}{\mathrm{N}}$

Dimana:

$\mathrm{K}=$ jumlah contoh sampel (KK)

$\mathrm{N}=$ jumlah jiwa per Keluarga $=4$

Berikut ini adalah perhitungan jumlah contoh yang diambil pada Kecamatan Klojen:

Jumlah penduduk Kecamatan Klojen adalah 134.885 jiwa, sehingga:

$\mathrm{S}=1 \sqrt{134885}$

$\mathrm{S}=367$ jiwa

$\mathrm{K}=\frac{367}{4}=92 \mathrm{KK}$

Jumlah KK yang dihasilkan dari perhitungan tersebut adalah 92 KK. Untuk memenuhi persyaratan pengambilan jumlah sampel sampah pada SNI 19-3964-1994 bahwa jumlah sampel minimal $100 \mathrm{~kg}$, maka jumlah $92 \mathrm{KK}$ memenuhi persyaratan pengambilan sampel. Hal ini dikarenakan laju timbulan sampah dihasilkan sebesar 0,33 kg/orang/hari [10]. Pada penelitian ini akan diambil $100 \mathrm{KK}$ (4 orang/KK), sehingga total berat sampah yang akan dihasilkan kurang lebih adalah $100 \mathrm{~kg}$.

Selanjutnya dilakukan penentuan persebaran titik sampel berdasarkan wilayah dengan nasabah bank sampah, non nasabah tetapi di RW yang mempunyai bank sampah, dan non nasabah di kelurahan yang mempunyai sedikit bank sampah. Pembagian lokasi sampling dilakukan pada 2 kelurahan dengan 3 kategori, yaitu nasabah bank sampah, non nasabah tetapi di RW yang mempunyai bank sampah, dan non nasabah di kelurahan yang mempunyai sedikit bank sampah. Kategori ditujukan untuk menentukan potensi peningkatan partisipasi masyarakat. Jumlah sampel terbanyak dilakukan pada nasabah bank sampah karena terdapat kemungkinan adanya nasabah yang sudah tidak aktif. Sehingga pembagian cluster dapat dilihat pada Tabel 1.

Tabel 1.

Jumlah sampel yang diambil di Kecamatan Klojen

\begin{tabular}{lc}
\hline Cluster & Jumlah KK \\
\hline Nasabah Bank Sampah & 50 \\
\hline $\begin{array}{l}\text { Non nasabah tetapi di RW yang mempunyai } \\
\text { Bank Sampah }\end{array}$ & 25 \\
\hline $\begin{array}{l}\text { Non nasabah di kelurahan yang mempunyai } \\
\text { sedikit Bank Sampah }\end{array}$ & 25 \\
\hline Total & 100 \\
\hline \hline
\end{tabular}

\section{B. Pengukuran Timbulan, Komposisi, dan Densitas}

Pengukuran timbulan sampah rumah tangga dilakukan dengan menggunakan metode Load-count yaitu sampah yang dikumpulkan oleh petugas gerobak dari sumber kemudian ditimbang satu gerobak sehingga diketahui masa sampah yang dihasilkan selama 8 hari. Sedangkan untuk perhitungan laju timbulan sampah rumah tangga memperhatikan jumlah penduduk (KK) yang sampahnya diangkut oleh petugas gerobak dan massa sampah yang dihasilkan. Pengukuran timbulan sampah juga dilakukan di setiap TPS di Kecamatan Klojen. Pengukuran timbulan sampah di TPS dilakukan dengan Mapping TPS yaitu mengukur volume sampah pada masing-masing gerobak yang masuk ke TPS, area pelayanan pengumpulan sampah, jumlah ritasi pengumpulan, dan jumlah sampah yang direduksi apabila petugas pengumpul melakukan pemilahan sehingga diketahui jumlah timbulan sampah yang dihasilkan satu TPS. Timbulan sampah dinyatakan dalam satuan berat (ton/hari).

Persamaan yang digunakan untuk menghitung timbulan sampah adalah sebagai berikut:

Timbulan Sampah per orang $\left(\frac{\mathrm{kg}}{\mathrm{org}}\right.$, hari $)$

$=\frac{\text { Berat sampah ( } \mathrm{kg} \text { fhari) }}{\text { jumiah penduduk yang disampling (orang) }}$.

Timbulan Sampah total ( $\mathrm{kg} / \mathrm{hari})$

= Timbulan Sampah per Orang (kg/org.hari) x Jumlah

Penduduk Kecamatan...

Karakteristik sampah yang diukur meliputi volume, densitas, dan komposisi sampah. Volume sampah diperoleh dari hasil pengukuran terhadap volume sampah pada tiap gerobak yang masuk ke TPS di Kecamatan Klojen. Melalui data tersebut, selanjutnya dapat dihitung densitas sampah. Densitas sampah yang dihitung adalah densitas sampah di gerobak TPS dan densitas sampah di truk menuju TPA. Densitas sampah dihitung menggunakan persamaan 4.3 sebagai berikut:

Densitas Sampah $\left(\frac{\mathrm{kg}^{\mathrm{a}}}{\mathrm{m}}\right)=$ Berat sampah ( $\mathrm{kg}$ )

Volume sampah $\left(\mathrm{m}^{3}\right)$

Selain itu, komposisi sampah yang dianalisis berdasarkan hasil sampling dapat diklasifikasikan dan digambarkan melalui diagram. Perhitungan densitas tiap komposisi sapah digunakan kotak densitas 40L sesuai dengan SNI 19-3964-1994. Perhitungan persentase komposisi digunakan rumus 4.4 sebagai berikut: 
Komposisi sampah $(\%)=$

$\frac{\text { Jenis rampah ( } \mathrm{hg})}{\text { Berat sampah }(100 \mathrm{~kg})} \times 100 \%$

\section{Pengurangan Sampah Rumah Tangga}

Pengurangan sampah rumah tangga dapat dianalisis berdasarkan hasil survei terhadap pengelolaan sampah berbasis masyarakat di Kecamatan Klojen, seperti Bank Sampah dan sektor informal (petugas pengumpul sampah dan pengepul). Adanya fasilitas Bank Sampah memberi pengaruh terhadap pengurangan sampah. Potensi reduksi Bank Sampah dan sektor informal belum terukur di Kecamatan Klojen.Reduksi sampah dari Bank Sampah dapat diketahui dari jumlah dan komposisi sampah yang masuk dalam jangka waktu tertentu. Reduksi sampah dari sektor informal diperoleh dari jumlah sampah yang dapat dipilah oleh petugas dan pengepul di TPS dalam kurun waktu tertentu. Reduksi sampah dinyatakan dalam satuan berat (kg/hari).

Pengukuran reduksi sampah juga dilakukan di TPS. Untuk mengukur timbulan sampah setelah dilakukan reduksi melalui berbagai pengelolaan, dilakukan penimbangan massa sampah yang dipilah oleh setiap petugas gerobak (yang melakukan pemilahan) di setiap TPS selama 2-3 hari kemudian diratarata. Petugas pengumpul melakukan pemilahan pada saat tiba di TPS sebelum membongkar sampah atau saat melakukan pengumpulan sampah di rumah tangga sehingga dapat mempengaruhi waktu pengumpulan.

\section{HASIL DAN PEMBAHASAN}

\section{A. Timbulan dan Komposisi Sampah}

Hasil pengukuran timbulan sampah rumah tangga menunjukkan jumlah sampah yang dihasilkan oleh tiap orang sebesar $0,28 \mathrm{~kg} / \mathrm{orang} / \mathrm{hari}$. Nilai ini sesuai dengan ketentuan dalam SNI 19-3983-1995 bahwa timbulan sampah untuk permukiman berkisar antara 0,25-0,40 kg/hari. Berikut adalah perhitungan timbulan sampah total di Kecamatan Klojen:

Total timbulan sampah

$=$ timbulan sampah per orang $\mathrm{x}$ jumlah penduduk

$=0,28 \mathrm{~kg} / \mathrm{jiwa} \cdot h a r i \mathrm{x} 134885$ jiwa

$=37896 \mathrm{~kg} / \mathrm{hari}$

Timbulan sampah permukiman untuk masing-masing kelurahan di Kecamatan Klojen yang dilakukan dengan cara yang sama dapat dilihat pada Tabel 2.

Tabel 2.

Timbulan Sampah Kecamatan Klojen Tiap Kelurahan

\begin{tabular}{llrr}
\hline \hline No & Kelurahan & $\begin{array}{c}\text { Jumlah } \\
\text { Penduduk } \\
\text { (jiwa) }\end{array}$ & $\begin{array}{c}\text { Timbulan Sampah } \\
\text { (kg/hari) }\end{array}$ \\
\hline 1 & Kasin & 15497 & 4354 \\
2 & Sukoharjo & 12021 & 3377 \\
3 & Kiduldalem & 6594 & 1852 \\
4 & Kauman & 13737 & 3859 \\
5 & Bareng & 16636 & 4674 \\
6 & Gadingkasri & 14279 & 4012 \\
7 & Oro Oro Dowo & 13616 & 3825 \\
8 & Klojen & 5919 & 1663
\end{tabular}

\begin{tabular}{llrr}
\hline \hline No & Kelurahan & $\begin{array}{c}\text { Jumlah } \\
\text { Penduduk } \\
\text { (jiwa) }\end{array}$ & $\begin{array}{c}\text { Timbulan Sampah } \\
\text { (kg/hari) }\end{array}$ \\
\hline 9 & Rampal Celaket & 6778 & 1904 \\
10 & Samaan & 12726 & 3575 \\
11 & Penanggungan & 17082 & 4799 \\
\hline Total & & 134885 & 37896 \\
\hline \hline
\end{tabular}

Berdasarkan perhitungan dan Tabel 2, dapat diketahui bahwa total timbulan sampah di Kecamatan Klojen sebesar $37895,7 \mathrm{~kg} / \mathrm{hari}$. Timbulan sampah terbesar dihasilkan pada Kelurahan Penanggungan, yaitu sebesar 4799 kg/hari. Selain dikarenakan jumlah penduduknya yang tinggi, daerah ini merupakan salah satu dengan kepadatan penduduk tinggi dan telah banyak perkembangan dari segi perdagangan, dan fasilitas umum.

Pengukuran timbulan sampah di TPS bertujuan untuk mengetahui timbulan sampah setelah dilakukan reduksi melalui berbagai pengelolaan sampah yang ada di Kecamatan Klojen. Pengukuran timbulan di TPS ini dilakukan dengan cara Mapping TPS yaitu, menghitung jumlah volume sampah yang masuk per hari, massa jenis sampah dan massa sampah yang dilapak oleh petugas pengumpul sampah di masingmasing TPS. Sehingga diketahui massa sampah yang dibawa ke TPA oleh alat pengangkut sampah. Pemetaan atau Mapping TPS ini dilakukan selama 10 hingga 12 jam pada semua lokasi TPS yang ada di Kecamatan Klojen antara lain TPS Malabar, TPS Wilis, TPS Seram, TPS Brantas, TPS Kartini TPS Wahidin, TPS Rampal Celaket, dan TPS Cianjur. Pada TPS Tawira tidak dilakukan pemetaan dan pengukuran timbulan sampah karena sampah berasal dari perkantoran pemerintahan Kota Malang yang merupakan sampah sejenis sampah rumah tannga. Timbulan sampah di tiap TPS Kecamatan Klojen yang sebelum terjadi reduksi oleh dapat dilihat pada Tabel 3.

Tabel 3

Timbulan sampah tiap TPS di Kecamatan Klojen

\begin{tabular}{|c|c|c|c|}
\hline Nama TPS & $\begin{array}{l}\text { Volume } \\
\text { Sampah } \\
\left(\mathrm{m}^{3} / \text { hari }\right)\end{array}$ & $\begin{array}{l}\text { Densitas } \\
\text { Sampah } \\
\left(\mathrm{kg} / \mathrm{m}^{3}\right)\end{array}$ & $\begin{array}{l}\text { Massa } \\
\text { Sampah } \\
\text { per TPS } \\
(\mathrm{kg})\end{array}$ \\
\hline TPS Malabar & 74 & \multirow{8}{*}{161,13} & 11945 \\
\hline TPS Wilis & 49 & & 7946 \\
\hline TPS Seram & 36 & & 5885 \\
\hline TPS Brantas & 29 & & 4736 \\
\hline TPS Kartini & 24 & & 3866 \\
\hline TPS Rampal Celaket & 27 & & 4357 \\
\hline TPS Wahidin & 16 & & 2522 \\
\hline TPS Cianjur & 51 & & 8160 \\
\hline Total & & & 49416 \\
\hline
\end{tabular}

Timbulan sampah setiap TPS bervariasi tergantung area yang dilayani dan jumlah penduduk pada area pelayanan. TPS Malabar merupakan TPS yang menghasilkan timbulan terbesar diantara TPS lainnya di Kecamatan Klojen, yaitu sebesar $11945 \mathrm{~kg} / \mathrm{hari}$. Sedangkan jumlah timbulan sampah pada TPS lain berbeda-beda. Timbulan sampah pada TPS Malabar tinggi karena jumlah penduduk yang dilayani tinggi, selain itu TPS Malabar mempunyai kapasitas TPS paling besar dibandingkan 
TPS lainnya yaitu memiliki 2 kontainer berkapasitas $8 \mathrm{~m}^{3}$ dan 1 dump truk sebanyak 2 ritasi sehingga jumlah sampah yang ditampung dapat lebih besar.

Berdasarkan hasil pemetaan TPS, persentase pelayanan TPS di Kecamatan Klojen sebesar $77 \%$, artinya $23 \%$ potensi timbulan sampah di Kecamatan Klojen telah dilakukan pengolahan yaitu diantaranya melalui bank sampah dan sektor informal atau timbulan sampah dari Kecamatan Klojen masuk ke TPS terdekat yang berada di Kecamatan lain.

Setelah mengetahui timbulan sampah rumah tangga, selanjutnya dilakukan pengukuran densitas sampah di gerobak. Perhitungan densitas sampah di gerobak dapat dilakukan dengan membagi berat sampah di gerobak dan volume sampah di gerobak. Densitas rata-rata sampah di alat pengumpul adalah sebesar $161,13 \mathrm{~kg} / \mathrm{m}^{3}$.

Komposisi didapatkan dengan melakukan pemilahan sampah yang dilakukan di sumber maupun di TPS. Pemilahan sampah dibagi beberapa macam antara lain sampah dapat dikomposkan (sisa makanan dan sampah kebun), sampah plastik (HDPE, LDPE, PP, PET, PS Sterofoam, PP bag, dan lain-lain), kertas (koran, HVS/duplek, tetra pack, karton, tissue, dan lain-lain), logam (besi, kaleng, kaleng baja, kaleng cans, non kaleng, dan kabel/tembaga), kaca (botol kaca dan kaca lain), kain, kayu, karet, diapers (popok dan non popok/pembalut), karet, B3, dan residu. Komposisi sampah rumah tangga Kecamatan Klojen terbesar adalah sampah dapat dikomposkan dan plastik yaitu berturut-turut sebesar 67,29\% dan $8,29 \%$. Komposisi sampah rumah tangga dapat dilihat pada Tabel 4.

Tabel 4.

Komposisi sampah rumah tangga di Kecamatan Klojen

\begin{tabular}{lc}
\hline \hline Komposisi Sampah & Persentase \\
\hline Dapat dikomposkan & $67,29 \%$ \\
Plastik & $8,29 \%$ \\
Kertas & $7,22 \%$ \\
Logam & $1,78 \%$ \\
Kaca & $1,06 \%$ \\
Kain & $1,90 \%$ \\
Kayu & $0,09 \%$ \\
Karet & $0,15 \%$ \\
Diapers & $8,00 \%$ \\
Residu & $3,66 \%$ \\
B3 & $0,57 \%$ \\
\hline Total & $100,00 \%$ \\
\hline \hline
\end{tabular}

B. Reduksi Sampah

Reduksi sampah disumber dilakukan oleh masyarakat melalui Bank Sampah. Jumlah bank sampah yang ada di Kecamatan Klojen sebanyak 93 bank sampah. Jumlah sampah yang direduksi berdasarkan tiap jenisnya dari beberapa bank sampah kemudian ditentukan rata-ratanya yang didapatkan melalui wawancara pada pegurus bank sampah. Jenis sampah yang dikumpulkan di bank sampah dapat dilihat pada Tabel 5 .
Tabel 5.

Jumlah sampah yang masuk ke Bank Sampah di Kecamatan Klojen

\begin{tabular}{lcc}
\hline \hline Jenis Sampah & $\begin{array}{c}\text { Rata-rata (kg/bank } \\
\text { sampah/hari) }\end{array}$ & $\begin{array}{c}\text { Komposisi sampah } \\
(\%)\end{array}$ \\
\hline Kertas & 1,99 & $57,21 \%$ \\
Plastik & 0,98 & $28,07 \%$ \\
Seng & 0,12 & $3,57 \%$ \\
Besi & 0,08 & $2,44 \%$ \\
Botol dan Kaca & 0,29 & $8,43 \%$ \\
Alumunium & 0,01 & $0,28 \%$ \\
\hline Jumlah & 3,48 & $100 \%$ \\
\hline \hline
\end{tabular}

Jumlah sampah yang direduksi berdasarkan tiap jenisnya dari beberapa bank sampah kemudian ditentukan rata-ratanya. Reduksi bank sampah di Kecamatan Klojen sebesar 0,1 $\mathrm{kg} / \mathrm{orang} / \mathrm{hari}$. Jenis sampah yang direduksi diantaranya kertas, plastik, logam dank kaca. Kertas mempunyai komposisi sampah paling besar yaitu sebesar 57,21\%. Sampah jenis kertas memiliki persentase komposisi terbesar dari sampah yang direduksi oleh bank sampah. Besarnya persentase komposisi sampah kertas karena pada umumnya sampah yang dihasilkan banyak sehingga jumlah yang tereduksi banyak. Selain itu jumlah sampah yang direduksi dipengaruhi oleh kebiasaan masyarakat, jenis aktifitas, jenis kota yang merupakan kota sedang dimana penggunaan plastik lebih kecil dibandingkan dengan kota besar, dan perekonomian masyarakat yang pada umumnya menengah atau menengah kebawah.

Jumlah persentase pelayanan penduduk kelurahan yang terlayani bank sampah dapat dilihat pada Tabel 6. Persentase ini untuk mengetahui cakupan pelayanan dari bank sampah. Bank Sampah pada umumnya dilaksanakan pada tingkat Rukun Tetangga (RT).

Tabel 6.

Persentase pelayanan Bank Sampah tiap kelurahan

\begin{tabular}{lrrrrr}
\hline \hline Kelurahan & $\begin{array}{r}\text { Jumlah } \\
\text { RW }\end{array}$ & $\begin{array}{r}\text { Jumlah } \\
\text { RT }\end{array}$ & $\begin{array}{r}\text { Penduduk } \\
\text { (orang) }\end{array}$ & $\begin{array}{r}\text { Jumlah } \\
\text { Bank } \\
\text { Sampah } \\
\text { (unit) }\end{array}$ & $\begin{array}{r}\% \\
\text { Pelayanan } \\
\text { BS }\end{array}$ \\
\hline Gadingkasri & 6 & 50 & 14279 & 25 & $50,0 \%$ \\
Oro-oro Dowo & 10 & 97 & 13616 & 4 & $4,1 \%$ \\
Bareng & 8 & 83 & 16636 & 7 & $8,4 \%$ \\
Kasin & 11 & 96 & 15497 & 19 & $19,8 \%$ \\
Kauman & 10 & 67 & 13737 & 5 & $7,5 \%$ \\
Sukoharjo & 7 & 57 & 12021 & 4 & $7,0 \%$ \\
Klojen & 7 & 47 & 5919 & 7 & $14,9 \%$ \\
Kiduldalem & 8 & 49 & 6594 & 2 & $4,1 \%$ \\
Rampal & 6 & 35 & 6778 & 6 & $17,1 \%$ \\
Celaket & 8 & 58 & 12726 & 8 & $13,8 \%$ \\
Samaan & 8 & 45 & 17082 & 6 & $13,3 \%$ \\
Penanggungan & & & & & $14,6 \%$ \\
\hline Rata-Rata & & & & & \\
\hline \hline
\end{tabular}

Jumlah nasabah tiap Bank Sampah berbeda-beda, tergantung tingkat partisipasi masyarakat di wilayah tersebut. Semakin banyak jumlah nasabah Bank Sampah di suatu wilayah, semakin banyak pula jumlah sampah yang dapat direduksi. Jumlah penduduk terlayani tiap Bank Sampah dapat dihitung dengan mengetahui jumlah nasabah (KK) dan rata- 
rata anggota keluarga di Kecamatan Klojen. Rata-rata anggota keluarga di salah satu kelurahan di Kecamatan Klojen sebesar 4,70 (Kantor Kelurahan Gadingkasri, 2017). Dari data penduduk yang terlayani tiap Bank Sampah, selanjutnya dapat dihitung berat tiap jenis sampah yang dapat direduksi tiap orang per bulan. Berikut contoh perhitungan pada salah satu bank sampah:

Penduduk terlayani $\quad B S=$ jumlah nasabah $\mathrm{x}$ rata-rata $\mathrm{KK}$ $=9$ orang $\mathrm{x} 4,70$ $=42$ orang

Reduksi per jenis sampah $\quad=\mathrm{kg}$ kertas/pend.terlayani M-013 $=2,88 \mathrm{~kg} / \mathrm{hari} / 42$ orang $=0,094 \mathrm{~kg} /$ orang.hari

Data jumlah penduduk terlayani tiap Bank Sampah dan jumlah reduksi sampah tiap orang per hari dapat dilihat pada Tabel 7 dan Tabel 8.

Tabel 7.

Jumlah penduduk terlayani Bank Sampah

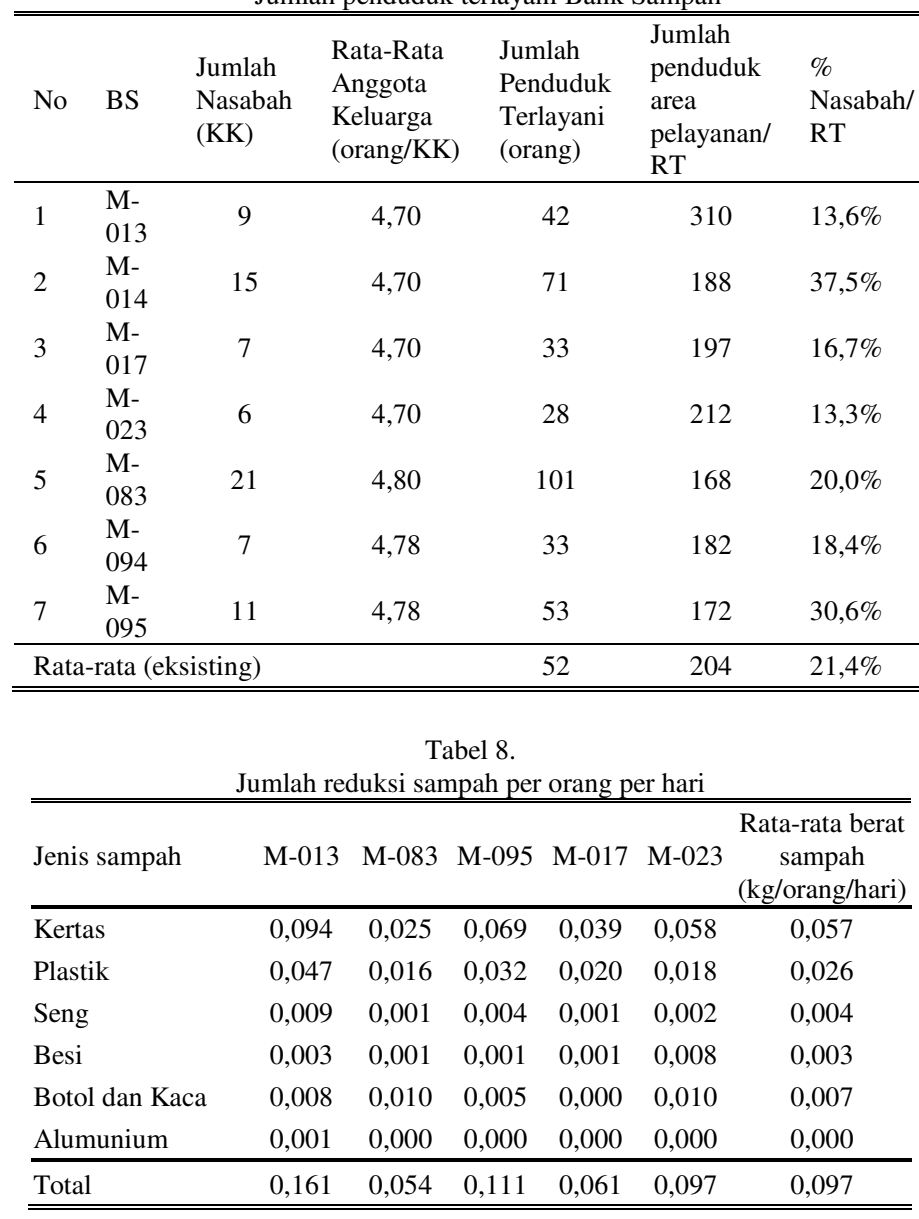

Berdasarkan hasil perhitungan Tabel 8 , dapat diketahui bahwa jumlah reduksi sampah per orang per hari pada Bank Sampah M-013 sebesar 0,161 kg/org/hari, Bank Sampah M083 sebesar 0,054 kg/org/hari, Bank Sampah M-095 sebesar 0,111 kg/org/hari, Bank Sampah M-017 sebesar 0,061 $\mathrm{kg} /$ org/hari, dan Bank Sampah M-023 sebesar 0,097 $\mathrm{kg} /$ org/hari. Sehingga rata-rata reduksi sampah dari kelima Bank Sampah tersebut adalah 0,1 kg/org/hari.
Jumlah sampah yang dapat direduksi oleh bank sampah tiap kelurahan dapat dilihat pada Tabel 8. Berikut merupakan contoh perhitungan persentase reduksi Bank Sampah pada Kelurahan Gadingkasri:

Penduduk Kel. Gadingkasri (a) $=14279$ orang

$\%$ Pelayanan Bank Sampah (b) $=50 \%$

$\%$ Nasabah Bank Sampah (c) $\quad=21,4 \%$

Reduksi BS (kg/orang/hari) (d) $=0,1 \mathrm{~kg} /$ orang/hari

Timbulan sampah (e) $\quad=4012 \mathrm{~kg} / \mathrm{hari}$

Jumlah sampah tereduksi

$=\mathrm{a} \times \mathrm{b} \times \mathrm{c} \times \mathrm{d}$

$=14279 \times 50 \% \times 21,4 \% \times 0,1 \mathrm{~kg} / \mathrm{org} / \mathrm{hr}$

$=148 \mathrm{~kg} / \mathrm{hari}$

$\%$ Reduksi sampah

= sampah tereduksi / e x $100 \%$

$=148,1 \mathrm{~kg} / \mathrm{hari} / 4012 \times 100 \%$

$=3,7 \%$

Hasil perhitungan selengkapnya dapat dilihat pada Tabel 9.

Tabel 9. Jumlah reduksi Bank Sampah tiap kelurahan

\begin{tabular}{lrrrr}
\hline Kelurahan & $\begin{array}{c}\text { Timbulan } \\
\text { Sampah }\end{array}$ & $\begin{array}{c}\text { Sampah } \\
\text { Tereduksi } \\
\text { (kg/hari) }\end{array}$ & $\begin{array}{c}\text { Timbulan } \\
\text { Sampah } \\
\text { setelah } \\
\text { Reduksi }\end{array}$ & $\begin{array}{c}\% \\
\text { Reduksi } \\
\text { Sampah }\end{array}$ \\
\hline Gadingkasri & 4012 & 148 & 3863 & $3,7 \%$ \\
Oro-oro Dowo & 3825 & 12 & 3814 & $0,3 \%$ \\
Bareng & 4674 & 29 & 4645 & $0,6 \%$ \\
Kasin & 4354 & 64 & 4290 & $1,5 \%$ \\
Kauman & 3859 & 21 & 3838 & $0,6 \%$ \\
Sukoharjo & 3377 & 18 & 3360 & $0,5 \%$ \\
Klojen & 1663 & 18 & 1645 & $1,1 \%$ \\
Kiduldalem & 1852 & 6 & 1847 & $0,3 \%$ \\
Rampal Celaket & 1904 & 24 & 1880 & $1,3 \%$ \\
Samaan & 3575 & 36 & 3539 & $1,0 \%$ \\
Penanggungan & 4799 & 47 & 4752 & $1,0 \%$ \\
\hline Jumlah & $\mathbf{3 7 8 9 5}$ & $\mathbf{4 2 3}$ & $\mathbf{3 7 4 7 2}$ & $\mathbf{1 , 1 \%}$ \\
\hline
\end{tabular}

Persentase pelayanan bank sampah di kecamatan masih kurang maksimal pemanfaatanya. Persentase pelayanan bank sampah dapat ditingkatkan dengan memperluas area pelayanan bank sampah. Pada umumnya cakupan pelayanan bank sampah adalah tingkat RT, sehingga perlu dimaksimalkan dengan meningkatkan pelayanan pada tingkat RW hingga kelurahan. Kendala dalam peningkatan persentase pelayanan adalah tempat untuk mengumpulkan sampah. Bertambahnya nasabah di bank sampah mengakibatkan meningkatnya jumlah sampah yang dikumpulkan sedangkan tempat yang tersedia terbatas. Oleh karena itu frekuensi penyetoran harus dijadwalkan dengan BSM pusat dengan baik agar tidak terjadi penumpukan sampah di tiap bank sampah.

Keberadaan sektor informal (petugas pengumpul sampah) yang melakukan pemilahan di masing-masing TPS sangat berpengaruh dalam mengurangi jumlah sampah yang masuk ke TPA. Kemampuan reduksi sampah petugas pengumpul sampah lebih besar dari bank sampah karena area pengambilan sampah yang lebih luas. Jumlah reduksi sampah oleh petugas pengumpul sampah dapat dilihat pada Tabel 10. 
Reduksi sampah oleh petugas pengumpul sampah dan pengepul di TPS

\begin{tabular}{|c|c|c|c|c|c|}
\hline \multirow{2}{*}{ Reduksi Sampah } & \multicolumn{4}{|c|}{ Jumlah Reduksi (kg//hari) } & \multirow{2}{*}{$\begin{array}{c}\text { Massa } \\
\text { tereduksi }\end{array}$} \\
\hline & Kertas & Plastik & Logam & Kaca & \\
\hline Jumlah (kg/hari) & 411 & 501 & 259 & 260 & 1431 \\
\hline Rata-rata & 51 & 63 & 32 & 32 & 179 \\
\hline$\%$ komposisi & $28,72 \%$ & $35,02 \%$ & $18,11 \%$ & $18,15 \%$ & $100,00 \%$ \\
\hline
\end{tabular}

Berdasarkan data pada Tabel 10 jumlah reduksi sampah terbesar pada jenis sampah plastik. Hal ini karena sampah plastik merupakan komposisi sampah paling besar yang dapat dimanfaatkan kembali sehingga petugas pengumpul paling banyak memilah jenis sampah plastik. Untuk sampah plastik petugas pengumpul sampah hanya memilah jenis botol plastik, plastik keras, dan plastik minuman gelas. Kemudian jenis sampah kertas paling banyak karena semua jenis sampah kertas laku jika dijual.

Jumlah reduksi sampah setiap petugas pengumpul sampah merupakan dasar untuk mengetahui jumlah sampah yang tereduksi di TPS. Perhitungan persentase reduksi sampah di TPS didapatkan dengan mengetahui perbandingan sampah yang tereduksi di TPS dengan jumlah timbulan sampah yang masuk di TPS. Persentase reduksi sampah di TPS dapat dilihat padal Tabel 11. Reduksi sampah yang dilakukan oleh petugas pengumpul sampah disetorkan kepada pengepul.

Tabel 11.

Reduksi sampah tiap TPS di Kecamatan Klojen

\begin{tabular}{lrrrr}
\hline \hline Nama TPS & $\begin{array}{c}\text { Massa } \\
\text { Sampah } \\
\text { per TPS } \\
(\mathrm{kg} / \mathrm{hari})\end{array}$ & $\begin{array}{c}\text { Reduksi } \\
\text { Sampah } \\
(\mathrm{kg} / \mathrm{hari})\end{array}$ & $\begin{array}{c}\text { Total } \\
\text { Massa } \\
(\mathrm{kg} / \mathrm{hari})\end{array}$ & $\begin{array}{c}\% \\
\text { Reduksi }\end{array}$ \\
\hline TPS Malabar & 11945 & 336 & 11610 & $2,81 \%$ \\
TPS Wilis & 7946 & 211 & 7734 & $2,66 \%$ \\
TPS Seram & 5885 & 254 & 5631 & $4,32 \%$ \\
TPS Brantas & 4736 & 182 & 4554 & $3,85 \%$ \\
TPS Kartini & 3866 & 87 & 3788 & $2,00 \%$ \\
TPS Rampal & 4357 & 125 & 4232 & $2,88 \%$ \\
Celaket & 2522 & 24 & 2497 & $0,96 \%$ \\
TPS Wahidin & 8160 & 210 & 7949 & $2,58 \%$ \\
TPS Cianjur & 49416 & 1431 & 47996 & $2,76 \%$ \\
\hline Total & & & & \\
\hline \hline
\end{tabular}

Reduksi paling besar terjadi di TPS Seram sebesar 4,32\% sedangkan reduksi paling kecil terjadi di TPS Wahidin sebesar $0,96 \%$. Perbedaan ini dikarenakan tidak semua petugas pengumpul sampah melakukan pemilahan. Hal ini disebabkan oleh terbatasnya lahan untuk melakukan pemilahan dan sebagian besar lokasi TPS berada di pinggir jalan. Reduksi yang dilakukan sektor informal dapat dimaksimalkan lagi dengan menyediakan tempat pemilahan di setiap TPS. Penyediaan tempat pemilahan akan memudahkan petugas pengumpul sampah untuk melakukan pemilahan serta adanya tempat untuk hasil pemilahan.

\section{KESIMPULAN}

Timbulan sampah rumah tangga di Kecamatan Klojen mempunyai komposisi sampah terbesar adalah sampah dapat dikomposkan. Sedangkan komposisi lainnya terdiri dari sampah plastik, kertas, diapers, kain, logam, kaca, kayu, karet, residu, dan B3. Timbulan sampah di TPS digunakan untuk mengetahui timbulan sampah setelah dilakukan reduksi melalui berbagai pengelolaan sampah yang ada di Kecamatan Klojen.

Reduksi sampah sejenis sampah rumah tangga terjadi di sektor informal. Bank Sampah dapat mereduksi sampah sebesar $1,1 \%$. Sedangkan sektor informal dapat mereduksi sampah sebesar 2,8\%. Jenis sampah yang dapat direduksi antara lain kertas, plastik, besi, dan kaca.

\section{UCAPAN TERIMA KASIH}

Ucapan terimakasih diucapkan kepada Dinas Lingkungan Hidup Kota Malang, Bank Sampah Malang, Pengawas TPS di Kecamatan Klojen, petugas pengumpul sampah, pengelola sampah fasilitas dan semua pihak, atas bantuan dan arahan yang telah diberikan kepada penulis ketika berada di lapangan saat pengambilan data.

\section{DAFTAR PUSTAKA}

[1] Wahyuni, E. T., Sunarto, Setyono, P. 2014. Optimalisasi Pengelolaan Sampah Melalui Partisipasi Masyarakat dan Kajian Extended Producer Responsibility (EPR) di Kabupaten Magetan, 6(1), 8-23.

[2] Pemerintah Daerah. 2016. Dokumen Strategi Sanitasi Kota Malang. Kota Malang.

[3] Pemerintah Daerah. 2011. Memorandum Program Sektor Sanitasi Kota Malang 2012-2015. Kota Malang.

[4] Sukarni, S. 2016. Exploring the Potential of Municipal Solid Waste (MSW) as Solid Fuel for Energy Generation: Case Study in the Malang City, Indonesia, Proceedings of the International Mechanical Engineering and Engineering Education Conferences (IMEEEC 2016), $1-7$.

[5] Purnama, A. R., Ciptomulyono, U. 2011. Model Optimasi Alokasi Pengelolaan Sampah dengan Pendekatan Inexact Fuzzy Linear Programming (Studi Kasus: Pengelolaan Sampah Di Kota Malang). Surabaya.

[6] Hardianto, Trihadiningrum, Y., Ciptomulyono, U. 2016. Municipal Solid Waste Recycling Facilities in Malang Raya, Indonesia, 11(9), 5886-5893.

[7] DKP Kota Malang. 2013. Pengelolaan Sampah di Kota Malang. Kota Malang.

[8] Purba, H. D., Meidiana, C., Adrianto, D. W. 2014. Waste Management Scenario through Community Based Waste Bank: A Case Study of Kepanjen District, Malang Regency, Indonesia. International Journal of Environmental Science and Development, 5(2), 212-216.

[9] Bank Sampah Malang. 2013. Data Nasabah Bank Sampah Malang Tahun 2013. Kota Malang.

[10] Dhokhikah, Y., Trihadiningrum, Y., Sunaryo, S. 2015. Community participation in household solid waste reduction in Surabaya, Indonesia. Resources, Conservation and Recycling, 102, 153-162. 